DOI: $10.2478 / \mathrm{rpp}-2014-0005$

$\mathrm{PhD}$ (pedagogical sciences), TETIANA KUCHAI Associate Professor of Cherkasy Bohdan Khmelnitsky National University Address: 81 Shevchenko Blvd., Cherkasy, 18031, Ukraine Phone: 0500769606 E-mail: tetyanna@ukr.net

\title{
LEGISLATIVE BASIS OF PEDAGOGICAL EDUCATION IN JAPAN
}

\section{ABSTRACT}

Legal framework policy of Japan in the field of education has been analyzed. The problem of influence of legislative materials on the development of education in Japan, its legislative support has been considered. It has been defined that directive materials affect the development of education system in Japan. Legislation policy of the country is represented by the following documents on education: laws, decrees, regulations etc., which are developed in accordance with the provisions of the Constitution and the Basic Law on Education of Japan, and contribute to the high level of school education and training of highly qualified teachers. The Constitution of Japan in 1946 laid the foundation for progressive changes in society and consolidated a new approach to education. This document provides a framework for creating laws, decrees, regulations, reform education. Achievements of Japanese civilization began to express themselves in the form of military advantage and economic prosperity, which was the impetus for their further development. Important role in solving this problem belongs to education, development of which is held by the legislative materials. In particular, there was established a number of laws, decrees, regulations, etc., the implementation of which contributed to higher levels of school and higher education. It has been defined that the concept of national identity within the structure of the student's moral consciousness should take priority position alongside with such concepts as conscience, justice, decency, kindness.

Key words: laws, Japan, education, reform, legislative materials.

\section{INTRODUCTION}

The high level of education in Japan is highly obliged to qualified teaching staff which is recognized around the world. Their training is conducted in colleges and universities. In order to be able to teach one must pass a qualifying exam and get a certificate: the initial (after college), medium (after university) or high (with Master's degree) (Корецкая, 2003). The legislative framework of Japanese policies concerning education is the laws on education - the main legal documents developed in accordance with the provisions of the state Constitution (Кремень, 1999).

\section{THE AIM OF THE STUDY}

To identify the impact of legislative materials on the development of the education system in Japan, its legislative supervision.

\section{THEORETICAL FRAMEWORK}

The beginning of modern education system in Japan was laid by the Education Act of 1872. The latter also established a system of school teacher training (the first educational institutions appeared). The representatives of all classes received equal opportunities for education. The conditions for learning were provided. At the end of the 19th century up to 
$90 \%$ of young Japanese went to school. Much funds were given to education (Озерська, 2006). Under this law the centralized education system is conducted, strictly controlled by the Ministry of Education, established in 1871 (Свердлова, 2004). According to the Law on Education purposes and objectives of teacher training were defined. The country was divided into eight districts (university districts). In each district the university was created. Each district was divided into 32 regions, in which schools were opened. Each region was divided into 210 subdistricts, in which primary schools were created. Thus, according to the law many universities, a large number of secondary and primary schools were opened (Озерська, 2006).

\section{RESULTS}

During this period, the following directive materials were issued:

- Imperial rescript on education (1890), according to which the meaning of life was a supreme dedication to the emperor of the country. Rescript was based on the basic dogmas of Confucianism and Shintoism (Корецкая, 2003).

Reading rescript was compulsory in every school since 1891, because it was the fundamental document for the education system till the end of World War II. Copies of the rescript, portraits of imperial family and a national flag were essential at every school. Teachers educated not "a man of knowledge" but "a man of integrity". Thus, moral education was under the spirit of nationalism and militarism, students were convinced in the "sacred right" of their country to dominate Asia and inculcate fanatical desire for selfsacrifice. In 1890 the "Comment" to rescript was published, which replaced the ethics course (Пляукшта, 2009).

- Imperial decree on "Great Principles of Education" (1879), called back to Confucian principles. On its basis the strict rules of schooling were formed, according to which it was necessary to read the text of the imperial rescript on education and honor the imperial family portraits (Давыдов, 1999).

- Laws: in 1879 - on three years of compulsory education; and in 1880 - the law on education and training, according to which the teacher as a state employee has to raise children under the slogan "emperor worship and love for the motherland", moral education is based not on European but on traditional moral values; and in 1886 the law on compulsory four-year degree was issued; and in 1890 education became free; in 1908 - the law was issued on compulsory six-year primary education. In the rules of school activities (1880) it was stated that among the subjects, dominant position should take moral education. When teaching most of the subjects it was necessary to introduce the idea of nationalism and militarism (Кочкина, 2005).

- According to the stated above the considerable attention was paid to the preparation of teachers' training in accordance with the objectives set by the government and Ministry of Education. In this regard numerous laws and regulations were issued, namely: the Law "On general regulation of Prefectural Colleges" (1883), "On the pedagogical school student quota" (1897), fixed standards of pedagogical school students according to the number of school-age children (Прасол, 2002), according to the law "On Military Duty" (1879) students and even teachers were exempted from military service, but the law "On Artillery Assembly" (1880) normed teacher attitude to politics. Teachers who supported democracy fell under suspicion (Озерська, 2006), in-laws "of additional benefits to teachers", "On pensions, and help school teachers who lost their bread-maker" (1890) and "On the basic school regulation" (1886) deals with the problem of social status of teachers in the education system, sources of financing pensions and fringe benefits to teachers (Озерська, 2006), the laws "On Certification" (1900), "On the secondary school" (1913), "On certification of 
educational personnel" (1949) there were explained the conditions and the course of issuing teaching certificates and employment, the laws "On the pedagogical school" (1886), "On education of teacher" (1897), promoted the reform of teacher training, considering that it must be based on moral virtues. However, the education of students was established on public funds for the representatives of the poor as well as for wealthy students (Озерська, 2006).

- It should be pointed out that in 1886 the Ministry of Education of Japan adopted the resolution "The main principles regulating education in pedagogical school", "Basic Principles of Regulation Prefectural pedagogical school", which contributed to the reform of teacher training, resulting in amplified militarization of teacher training, centralization education authorities and state bureaucratic control, the teacher was the ideal for students, deprived of religious and political beliefs (Озерська, 2006).

- In 1872, the total Education Code appeared, according to which Japan was opened to the penetration of European science and pedagogy. The basis was taken from the German education system. In the short essay "History of Japan" Zhukov points out the significant contribution to the study of Western education leadership experience "Movement for Freedom and People's Rights" by Yu. Fukudzava, who stated in the 19th century the three principles of education:

- "Education for All";

- "Equality for All";

- "Parenting personal independence and free individuality".

The scientists emphasized that Confucianism denies those scientific principles that had promoted Western civilization (Жуков, 1939).

The manual "Japanese modern culture. Meiji Era" the scientists Hryshelyeva L. and Chehodar N. emphasize that the use of Western standards (intellectual, cultural) hurt the pride of the Japanese and they believed that such dependence may result in a threat to their national spiritual values (Гришелева \& Чегодарь, 1998).

At schools the teachers were the priests and foreign professionals, teachers, samurai who administered a brutal system of training and education (Пляукшта, 2009).

There was an education reform. In 1868 Meiji Reform was set up, which was seen as a part of measures to accelerate the modernization of Japan, lagging behind the West. The reform established a modern education system in Japan (Кочкина, 2005). In 1886 the reform, which is characterized by the rapid development of education under state control, was introduced. Standardized educational content introduced a system of qualifying examinations for teaching staff. Educating was in the world of the ready charts and behaviors (Корецкая, 2003). It should be emphasized that according to the constitution in 1868 Shintoism became the state religion and on the first place there was the cult of the emperor, whose constitution declared "sacred and inviolable" (Кочкина, 2005). The Law on Education, the situation in 1880 and other legislation progressively the system of "moral education" were used as an instrument of ideological influence and played a crucial role in shaping the psychology of nationalism and militarism inform policy, not only serving to bring up moral qualities necessary for the harmonious functioning of society as it was before.

This phase in the history of education in Japan was meant to raise a generation able to enrich and strengthen the state and maintain a traditional way of government in Japan, where the first place is not pushing welfare of the individual and the state. Philosophical inspiration for this idea was the Education Minister A. Mori, who developed the "ideology of the state", according to which the orders of the minister of education in primary schools aimed to humble upbringing loyalists who would also be literate and physically developed. 
At the beginning of the 20th century the government introduced a complete censorship of textbooks. It should be noted that one of the functions of the Ministry of Education was the "oversight of views". The first supervisor was "Bureau on oversight of students" (1929). In high schools and universities the post "supervisor" was introduced who was responsible for the moral education of students. Because of wrong thoughts, arrests were carried out of thousands of citizens (Пляукшта, 2009).

The above mentioned facts show that the educational policy of the government has played a significant role in the growth of nationalism in Japan. Achievements of Japanese civilization began to be expressed not in the form of military benefits and the economic prosperity that was the impetus for further development (Прасол, 2002). Education played an important role in solving this problem, its development was held by legislative materials. In particular, there were established a number of laws, decrees, regulations, etc., the implementation of which contributed to a higher level of schooling and higher education.

Since early 60s Japan turned to a rapid modernization of the national economy, which was dependent on the maintenance of its qualified workforce, which led to the fact that it was necessary to focus on an average student, who quickly mastered the material (Кремень, 1999). This so-called "standard human cogs" provided the requirements of the country with the necessary staff. Only after a while there appeared a lack of talented, creative people who had to provide the system of management and as a result Japan began to lag behind America and Western Europe. However, the Japanese paid considerable attention to education. Education - the basic intellectual value. It should be noted that this country gave great importance to investment in education. Japanese schools are recognized as the world's most effective ones (Корецкая, 2003). Thus, in 50-60s according to the educational level of people aged 25-34 Japan has overtaken the developed countries of Europe and lagged behind only the United States (the same source). Continuous improvement of legislation contributed to the adaptation of education to the socio-economic development.

Analysis of the legislative materials that regulated the education system after the Second World War, shows the concern of the government, government departments and agencies towards the development of the education system and its legislative support.

We believe that the law "On educators" (1974) is extremely important for the status of teachers, because it assigned that their salary is higher than that of other employees.

Central Council for Education in Japan, founded in 1962, developed the programs: "The formation of man (Hitodzukuri)" (1962), "The image of an ideal Japanese" (1965). The basic idea of the program is the pursuit of harmonious education of the individual, including intellectual and physical development, moral education, cultural and artistic development. The programs are based on Confucian philosophical system and principles of national education (Салимова, 2008). The nature of educational reform in Japan depends on the historical situation in the country (Hirokazu Ouchi, Eiti Komori, Tetsuya Takahashi\& Akiko Miyake, 2006). Under the guidance of experts' recommendations from the United States (1947) an educational reform took place, as a result the curriculum got rid of chauvinistic ideas, decentralization of the education pyramid took place, the modern school structure was formulated (Давыдов, 1999). The education system of the $80 \mathrm{~s}$ of the 20th century got a task to find only talented, originally thinking people among Japanese. But the originality of thought had to be based on the Japanese ideology and national identity. In 1984 there was a reform of education, which aimed at introducing new challenges of time and cultural achievements into the education system, as well as to improve moral education (Пляукшта, 2009). The same reform in Japan introduced the individualized approach in learning, NIT and extensive study of foreign languages (Озерська, 2006). 
Reform of Continuing Education (1987) outlined the ways of creating the conditions for lifelong learning, self-development of the citizens throughout life (Кочкина, 2005).

So, as a result of the reform of the education system, particularly during the 1970-1990s the changes in education (both secondary and higher) were introduced according to the needs of society. The Ministry of Education assigns the curriculum for universities and colleges but their contents and methods were due to the institution of higher education (Корецкая, 2003).

It should be noted that in 1997 the Ministry of Education, Science, Sports and Culture of Japan created a generalizing project of educational reforms in the $21^{\text {st }}$ century as based on the achievements (Свердлова, 2004).

In 2006 the Basic Law on Education in Japan replaced the Act of 1947. It is extremely important for the successful building of "a beautiful country and society" - the spiritual unity of the nation, aimed at achieving prosperity (Галич, 2007).

In the updated form the Basic Law on Education offers some new approaches to the development of higher education, namely rapid social change, the development of intellectual society and the intensification of competition within and outside the country (Грищенко, 2012).

The Basic Law on Education with all the amendments is intended to provide a legal framework for the necessary reforms in the country to give the urge for social life, to change the consciousness of the Japanese and identify further successful development of the nation for years, to build a new "a beautiful country" - to provide spiritual unity of the nation, which will aim to achieve prosperity and success in international politics (Пляукшта, 2009).

The problem of moral and patriotic education in modern Japan was investigated by Yu. Plyaukshta (Пляукшта, 2009). She notes that in the early twenty-first century Japanese government began to raise the subject of patriotism. Indeed, in the country that has made great improvements in the economy, in cultural and humanitarian expansion in the Far East and Southeast Asia, the problem of fostering a sense of pride for the country, people and culture remained unsolved. At present, the government is trying to change the nation's attitude to this issue, taking into consideration that nationalism in the minds of people is still associated with the doctrine of "great power Yamato", which collapsed after the Second World War. At the beginning of the new millennium, the government actively conducts explanatory work in the field of developing the patriotism. It focuses on the love to the homeland and respect to other nations, their culture, traditions and history.

According to Yu. Plyaukshta's thesis (Пляукшта, 2009) the representatives of the older generation are more focused on the need to develop love of country and patriotism than younger people.

The Basic Law on Education, according to government, will keep the Japanese national identity; give every member of society a sense of pride of being a part of great culture and history; and also to help the individual based on the best features of the Japanese national character.

\section{CONCLUSIONS}

In our opinion, the concept of national identity within the structure of the moral consciousness of the student should take priority position alongside with such concepts as conscience, justice, decency, kindness. The materials presented show that the directive materials influence the development of the education system in Japan. The legislative policy of this country is represented by the following documents on education: laws, decrees, regulations, etc., which are developed in accordance with the provisions of the Constitution 
and the Basic Law on Education in Japan and contribute to its high level of school education, and training of the highly qualified teachers.

\section{REFERENCES}

1. Корецкая, С. В. (2003). Семейное воспитание в традиционных культурах (На материале Японии и Северного Кавказа) [Family education in traditional cultures (On a material of Japan and the North Caucasus)]. Doctoral thesis. Владикавказ, 206 c. (in Russian)

2. Озерська, О. Ю. (2006). Професійна підготовка вчителів у вищих навчальних закладах Японії [Tеacher training in higher education establishments of Japan]. Doctoral thesis. Харків, 212 c. (in Ukrainian)

3. Свердлова, Т. Г. (2004). Теоретичні засади процесу гуманізації освіти в Японії [The theoretical basis of the process of humanization of education in Japan]. Doctoral thesis. Київ, 280 c. (in Ukrainian)

4. Пляукшта, Ю. Н. (2009). Концепция морально-патриотического воспитания в современной Японии [The concept of moral and patriotic education in modern Japan]. Doctoral thesis. Москва, 198 с. (in Russian)

5. Кочкина, А. (2005). Формирование нравственных качеств личности в традииионной системе воспитания (На примере Японии) [Formation of moral qualities of the person in the traditional education system (the example of Japan)]. Doctoral thesis. Карачаевск, 178 c. (in Russian)

6. Прасол, А. Ф. (2002). Японское образование в эпоху Мэйдзи. 1868-1912 [Japanese education in the Meiji era. 1868-1912]. Владивосток: Дальнаука. (in Russian)

7. Жуков, Е. М. (1939). История Японии: Краткий очерк [History of Japan: A Brief Outline]. Москва: Соцэкгиз. (in Russian)

8. Гришелева, Л. Д., Чегодарь, Н. И. (1998). Японская культура нового времени. Эпоха Мэйдзи [Japanese culture is a new time. Meiji era]. Москва: Восточная литература. (in Russian)

9. Кремень, В. Г. (1999). Освітня ідеологія і політика в Україні і світі [Educational ideology and politics in Ukraine and worldwide]. Учитель [Teacher], № 11-12, c. 2-9. (in Ukrainian)

10. Салимова, К. И. (2008). Педагогическое наследие Востока [Pedagogical heritage of the East]. Москва: Изд-во Московского психолого-социального ин-та; Воронеж: Модэк. (in Russian)

11. Давыдов, В. В. (1999). Российская педагогическая энииклопедия. В 2-х томах [Russian Pedagogical Encyclopedia in 2 volumes]. Москва: Большая российская энциклопедия. (in Russian)

12. Грищенко, I. М. (2012). Стан та особливості управління вищою освітою в Японії [State and features of higher education in Japan]. Retrieved December 01, 2013 from: http://www.yourdatabase.org.ua/obshhestvo/stan-ta-osoblivosti-upravlinnya-vishhoyu-osvitoyuv-yaponi\%D1\%97.html (in Ukrainian)

13. Галич, Ю. Н. (2007). Изменения в Основном законе об образовании Японии. Морально-патриотическое воспитание в высшей школе [Changes in the Basic Education Act of Japan. Moral and patriotic education in high school]. Retrieved December 01, 2013 from: http://logosbook.ru/VOS/11_2007/16-21.pdf (in Russian)

14. Hirokazu Ouchi, Eiti Komori, Tetsuya Takahashi, Akiko Miyake (2006). All Japan Network "Stop deterioration Education Act!". Retrieved: December 01, 2013 from: http:/kyokiren seesaa.net./30050573.html 